stating, and it would have been judged on its merita. This witness was very likely a lickspittle of the murderers. He was probably of a low mental type, one whose sense of right and wrong was confused, and his view of the turpitude of certain actions by no means clear and well defined. In a word, he was most likely one of the easy-going, harmless class who has never been subjected to harsh treatment, since it has been his lot, perhaps, to do nothing to rouse the ire and bring himself under the oppression or remorseless attacks of those in power.

The Lord Justice Clerk commended Mr. Guthrie Smith as one who had acted wisely. We might ask if it is wise to leave a witness out of account, though insane, especially one said to be for the defence. Sheriff Campion's view of wisdom in this connection is antipodal to Lord Moncreiff's, and if one is right the other must be wrong.

It was said in defence that the attendants did not intend to kill the patient. It is a matter of less moment to know what they intended than what they did. They killed him inch by inch by breaking rib after rib of his body till twelve ribs were broken. Twelve " bony" witnesses these, that speak with no dubiety as to their intentions. It was not an iron image of a man they were operating upon, but one of flesh and blood like themselves, and to say that they did not intend murdering the patient-at least, that they had any particular concern whether they did 80 or not-is contrary to reason and common sense.

The jury came to the decision that the attendants were guilty of a grose assault, and recommended one of the two to the leniency of the Court. The Judge, in passing sentence, seemed to have left this recommendation of the jury entirely out of account, and sentenced each of them to three months' inprisonment. Thirteen weeks had been passed by them in prison previous to the trial.

In asylums no two attendants are on an exact equality, and in this murder the principal of the two, as the mainspring of the proceedings, must have been the more guilty of the two.

Next to the loss of character there is, perhaps, no evil that can overtake a man so great as insanity, for, independent of the suffering it brings along with it, the stigms of being, or having been insane is not very easily borne.

The City of Glasgow Bank Directors - men who certainly not willingly, but by the force of an overpowering tide of circumstances, were led to commi reprehensible actions in finance-were sentenced, several of them to eight months and two of them to eighteen months' imprisonment, while men appointed and paid for taking care of a poor lunatic, and who, by their most unjustifiable and cruel treatment, cause his death, are sentenced to three months' imprisonment only. This certainly does not look like even-handed justice. Mercy is the noblest attribute of the Almighty, and judgment mingled with mercy is the principle on which men should act in dispensing justice to their fellow men; yet, as there is hardly a day in which harshness and over-severity in one form or another are not practised in asylums for the insane, it seems to us that these things will rather be increased than dimin. ished by a judgment like that of the Lord Justice Clerk in cases such as this which at present has been brought under our notice.

$$
\text { I am, dear Sir, }
$$

\title{
MISLEADING EXAMPLE IN THE CENSUS SCHEDULES.
}

The following has appeared in The Scotsman:-

" Stirling, April 2, 1881.

" $\mathrm{SIR}-\mathrm{It}$ is much to be regretted that in the directions for filling in the census paper one of the examples given on the back of the schedule will lead people to make returns which must lessen the value of the results. Householders are asked to state if any member of their family be deaf or dumb, blind, an imbecile 
or idiot, or a lunatic. One would think that in these latter definitions it was desired to bring out the distinction between idiocy and insanity. The word imbecile or idiot is, by medical men at least, always used to signify those who suffer from mental deficiency resulting from disease or malnutrition of the brain, occurring either before birth or in early childhood; and one who becomes fatuous from the degenerative changes of old age, or disease occurring after the years of childhood are past, is, in medical language, a 'dement' or demented, and classed under the head of lunacy. The example given in the schedule is as follows:- Ellen Douglas, mother, widow, age 71, annuitant, born in Canada, imbecile.' Setting aside the question whether an imbecile can legally hold an annuity, most people would conclude that Mrs. Ellen Douglas must have lost her mental faculties after being married. In that case this unfortunate lady ought to have been returned as a lunatic, not an imbecile. Hundreds of householders will thus be induced to use the word 'imbecile' for their lunatic relations, all the more so that it seems a milder or less disagreeable term. It is true that in the schedules people are expecter to state whether those returned as imbecile or idiotic are so from birth ; but then a large number of idiots and imbeciles have been born apparently healthy, and have become imbecile or idiotic, from diseases of the nervous system after birth. The broad distinction between imbeciles or idiots and lunatics is confounded and lost by this unfortunate example. There is no doubt that our statistics of lunacy will thus be of inferior exactness, and not comparable to those of other countries, where the distinction between idiocy and insanity is properly made in the census.

"I am, \&c.,

"William W. Ireland."

\section{ON THE ADVANTAGES OF TOUGHENED GLASS FOR ASYLUM} WINDOWS.

Borough Asylum, Gosforth, Newcastle-on-Tyne.

SIR-With reference to your letter to the clerk of the asylum requesting him to inform you if the toughened window glass has given satisfaction here, I have to inform you that it has gradually been substituted for ordinary window glass here, since the 1st of February, 1877, and that I have every reason to be satisfied with it. The cost is about five times that of ordinary glass, but in the four years which it has been in use, it has more than repaid the first outlay, and only one half of the quantity ordered at that date has been used; in addition to its being in the end more economical, it has the advantage that when a pane is broken, which happens occasionally when a good deal of violence is exhibited, the fractured pieces have blunt edges and thus many injuries are avoided. I am, your obedient servant, R. H. B. WICKHAM, F.R.C.S. Medical Superintendent.

The glass is to be obtained of Messrs. Gardner, 453, Strand, London. The measure of the windows has to be sent, and after a few weeks a supply of panes is sent. At Bethlem we have ordered a supply, and in the course of a very short time we shall be glad to show the result of the trial.

Geo. H. SAVAGE.

\section{INTERNATIONAL MEDICAL CONGRESS.}

As a paper is expected from the Superintendent of Gheel it is to be hoped that those among our countrymen who have paid most attention to the more recent developments of the non restraint system, will not only attend but will also contribute plans of their detached houses, and such other home-like or village modes of grouping and treating the insane. 